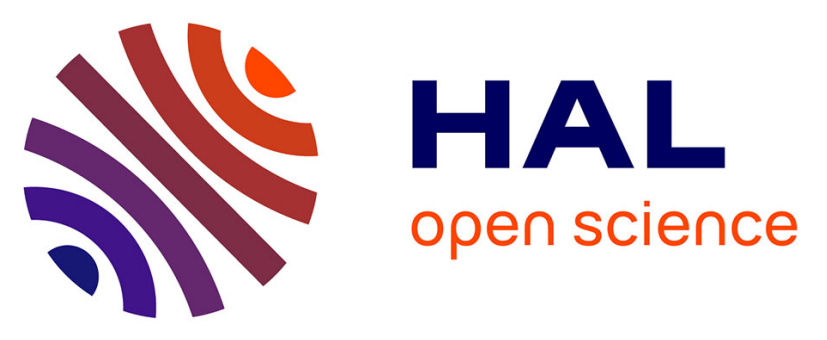

\title{
Reactions of $\mathrm{OH}$ radicals with 2-methyl-1-butyl, neopentyl and 1-hexyl nitrates. Structure-activity relationship for gas-phase reactions of $\mathrm{OH}$ with alkyl nitrates: An update
}

Yuri Bedjanian, Julien Morin, Manolis Romanias

\section{To cite this version:}

Yuri Bedjanian, Julien Morin, Manolis Romanias. Reactions of $\mathrm{OH}$ radicals with 2-methyl1-butyl, neopentyl and 1-hexyl nitrates. Structure-activity relationship for gas-phase reactions of $\mathrm{OH}$ with alkyl nitrates: An update. Atmospheric Environment, 2018, 180, pp.167 - 172. 10.1016/j.atmosenv.2018.03.002 . hal-01804174

\section{HAL Id: hal-01804174 \\ https://hal.science/hal-01804174}

Submitted on 12 Jan 2022

HAL is a multi-disciplinary open access archive for the deposit and dissemination of scientific research documents, whether they are published or not. The documents may come from teaching and research institutions in France or abroad, or from public or private research centers.
L'archive ouverte pluridisciplinaire HAL, est destinée au dépôt et à la diffusion de documents scientifiques de niveau recherche, publiés ou non, émanant des établissements d'enseignement et de recherche français ou étrangers, des laboratoires publics ou privés. 
Reactions of OH Radicals with 2-Methyl-1-Butyl, Neopentyl and 1-Hexyl Nitrates. Structure-Activity Relationship for Gas-Phase Reactions of $\mathrm{OH}$ with Alkyl Nitrates: an Update

\author{
Yuri Bedjanian, ${ }^{*}$ Julien Morin, ${ }^{1}$ Manolis N. Romanias ${ }^{2}$
}

Institut de Combustion, Aérothermique, Réactivité et Environnement (ICARE), CNRS and Université d'Orléans, 45071 Orléans Cedex 2, France

\footnotetext{
* Corresponding author. CNRS/ICARE, , 45071 Orléans Cedex 2, France. E-mail: yuri.bedjanian@cnrs-orleans.fr (Y. Bedjanian)

${ }^{1}$ Now at Aix Marseille Universite, CNRS, LCE, 13331, Marseille, France.

${ }^{2}$ Now at IMT Lille Douai, SAGE, F-59508, Douai, France.
} 


\section{ABSTRACT}

The kinetics of the reactions 2-methyl-1-butyl (2M1BNT), neopentyl (NPTNT) and 1-hexyl nitrates $(1 \mathrm{HXNT})$ with $\mathrm{OH}$ radicals has been studied using a low pressure flow tube reactor combined with a quadrupole mass spectrometer. The rate constants of the title reactions were determined under pseudo-first order conditions from kinetics of $\mathrm{OH}$ consumption in excess of nitrates. The overall rate coefficients, $k_{2 \mathrm{M} 1 \mathrm{BNT}}=1.54 \times 10^{-14}(T / 298)^{4.85} \exp (1463 / \mathrm{T})(\mathrm{T}=278$ $538 \mathrm{~K}), k_{\mathrm{NPTNT}}=1.39 \times 10^{-14}(T / 298)^{4.89} \exp (1189 / \mathrm{T})(\mathrm{T}=278-500 \mathrm{~K})$ and $k_{1 \mathrm{HXNT}}=2.23 \times 10^{-13}$ $(T / 298)^{2.83} \exp (853 / \mathrm{T}) \quad \mathrm{cm}^{3}$ molecule $\mathrm{s}^{-1} \quad(\mathrm{~T}=306-538 \mathrm{~K}) \quad$ (with conservative $15 \%$ uncertainty), were determined at a total pressure of 1 Torr of helium. The yield of trimethylacetaldehyde $\left(\left(\mathrm{CH}_{3}\right)_{3} \mathrm{CCHO}\right)$, resulting from the abstraction by $\mathrm{OH}$ of an $\alpha$ hydrogen atom in neopentyl nitrate, followed by $\alpha$-substituted alkyl radical decomposition, was determined as $0.31 \pm 0.06$ at $\mathrm{T}=298 \mathrm{~K}$. The calculated tropospheric lifetimes of 2M1BNT, NPTNT and 1HXNT indicate that reaction of these nitrates with OH represents an important sink of these compounds in the atmosphere. Based on the available kinetic data, we have updated the structure-activity relationship (SAR) for reactions of alkyl nitrates with $\mathrm{OH}$ at $\mathrm{T}=298 \mathrm{~K}$. Good agreement (within 20\%) is obtained between experimentally measured rate constants (total and that for $\mathrm{H}$-atom abstraction from $\alpha$ carbon) and those calculated from SAR using new substituents factors for almost all the experimental data available.

Keywords: Alkyl nitrates, OH, Kinetics, Atmospheric lifetime, Structure-activity relationship (SAR). 


\section{Introduction}

Organic nitrates are important atmospheric species which are formed during oxidation of volatile organic compounds in the atmosphere through addition channel of the reaction of peroxy radicals with $\mathrm{NO}$ and also in the $\mathrm{NO}_{3}$-initiated oxidation of unsaturated organics (Finlayson-Pitts and Pitts, 2000). Being temporary reservoirs of NOx with atmospheric lifetimes from a few days to a few weeks (Atkinson et al., 2006; Clemitshaw et al., 1997; Talukdar et al., 1997a; Talukdar et al., 1997b), organic nitrates play a key role in the distribution of reactive nitrogen by undergoing long-range transport in the free troposphere. The assessing of the atmospheric impact of organic nitrates requires the information on both their lifetime and the mechanism of their oxidation in the atmosphere leading $\mathrm{NO}_{\mathrm{x}}$ recycling.

In our recent work (Bedjanian et al., 2017; Morin et al., 2016; Romanias et al., 2015) we have studied reaction of $\mathrm{OH}$ radicals with a series of alkyl nitrates containing from 2 to 5 carbon atoms. In the present work, we report new experimental data on the reactions of $\mathrm{OH}$ with three other nitrates, two $\mathrm{C}_{5}$ alkyl nitrates of different structure, 2-methyl-1-butyl $\left(\mathrm{CH}_{3} \mathrm{CH}_{2} \mathrm{CH}\left(\mathrm{CH}_{3}\right) \mathrm{CH}_{2} \mathrm{ONO}_{2}, 2 \mathrm{M} 1 \mathrm{BNT}\right)$ and neopentyl $\left(\left(\mathrm{CH}_{3}\right)_{3} \mathrm{CCH}_{2} \mathrm{ONO}_{2}, \mathrm{NPTNT}\right)$, and a linear $\mathrm{C}_{6}$, 1-hexyl (1- $\left.\mathrm{C}_{6} \mathrm{H}_{13} \mathrm{ONO}_{2}, 1 \mathrm{HXNT}\right)$, nitrate:

$$
\begin{aligned}
& \mathrm{OH}+\mathrm{CH}_{3} \mathrm{CH}_{2} \mathrm{CH}\left(\mathrm{CH}_{3}\right) \mathrm{CH}_{2} \mathrm{ONO}_{2} \rightarrow \text { products } \\
& \mathrm{OH}+\left(\mathrm{CH}_{3}\right)_{3} \mathrm{CCH}_{2} \mathrm{ONO}_{2} \rightarrow \text { products } \\
& \mathrm{OH}+1-\mathrm{C}_{6} \mathrm{H}_{13} \mathrm{ONO}_{2} \rightarrow \text { products }
\end{aligned}
$$

The available data on the rate constants of the reactions (1) - (2) are limited to one room temperature study for each reaction (Atkinson et al., 1984; Becker and Wirtz, 1989). Reaction (3), to our knowledge, has not been studied previously. In the present paper, we report the first measurements of the temperature dependence of the rate constants of the reactions (1) (3) and the yield of trimethylacetaldehyde $\left(\left(\mathrm{CH}_{3}\right)_{3} \mathrm{CCHO}\right)$, resulting from the abstraction by 
$\mathrm{OH}$ of an $\alpha$-hydrogen atom in neopentyl nitrate, followed by the formed $\alpha$-substituted alkyl radical decomposition, at $\mathrm{T}=298 \mathrm{~K}$.

Finally, based on the kinetic data from this group (including those from the present study) and those available in the literature, we have updated the structure-activity relationship (SAR) for reactions of alkyl nitrates with $\mathrm{OH}$ at $\mathrm{T}=298 \mathrm{~K}$. In particular, it is shown that SAR, newly updated in this work, allows to reproduce the rate constants of most investigated reactions of $\mathrm{OH}$ with alkyl nitrates within $20 \%$ accuracy, and, potentially, can be used to predict not only the total rate constants but also primary products of the unknown (not yet investigated experimentally) reactions of $\mathrm{OH}$ with alkyl nitrates, i.e. to determine the atmospheric lifetime and first steps of the oxidation mechanism of these important atmospheric species.

\section{Experimental Section}

Experiments were carried out at 1 Torr total pressure of helium using a modulated molecular beam mass spectrometer (MS) combined with a discharge-flow system. Depending on temperature of the measurements two flow reactors were used. The first one (thermostated Pyrex tube of $45 \mathrm{~cm}$ length and $2.4 \mathrm{~cm}$ i.d. covered with halocarbon wax) was employed at low temperatures of the study (278 - 345 K) (Bedjanian et al., 1999a, b; Romanias et al., 2015). The second flow reactor, a Quartz tube (45 $\mathrm{cm}$ length and $2.5 \mathrm{~cm}$ i.d.) with an electrical heater and water-cooled extremities (Fig. S1, Supplementary Data) (Morin et al., 2016; Morin et al., 2015), was used at higher temperatures (455 - 538) K.

$\mathrm{OH}$ radicals were produced in a fast reaction of hydrogen atoms, generated in a microwave discharge of $\mathrm{H}_{2} / \mathrm{He}$ mixture, with excess $\mathrm{NO}_{2}$ :

$$
\mathrm{H}+\mathrm{NO}_{2} \rightarrow \mathrm{OH}+\mathrm{NO}
$$


and detected as $\operatorname{HOBr}^{+}(m / z=96 / 98)$ (Bedjanian et al., 1999a, b) after being scavenged with an excess of $\mathrm{Br}_{2}\left(\left[\mathrm{Br}_{2}\right] \approx 5 \times 10^{13}\right.$ molecule $\left.\mathrm{cm}^{-3}\right)$, added at the end of the reactor $5 \mathrm{~cm}$ upstream of the sampling cone of the mass spectrometer (Figure S1), via reaction:

$$
\mathrm{OH}+\mathrm{Br}_{2} \rightarrow \mathrm{HOBr}+\mathrm{Br}
$$

The chemical conversion of $\mathrm{OH}$ to $\mathrm{HOBr}$ was also used for the measurements of the absolute concentrations of the radicals: $[\mathrm{OH}]=[\mathrm{HOBr}]=\Delta\left[\mathrm{Br}_{2}\right]$ (Bedjanian et al., 1999a, b), i.e. concentrations of $\mathrm{OH}$ were determined from the consumed fraction of $\left[\mathrm{Br}_{2}\right]$.

The nitrates were synthesized in the laboratory via slow mixing of the corresponding alcohol with $\mathrm{H}_{2} \mathrm{SO}_{4}: \mathrm{HNO}_{3}(1: 1)$ mixture at temperature $<5^{\circ} \mathrm{C}$ (Boschan et al., 1955; Morin et al., 2016). The synthesized nitrate was degassed before use. Gas chromatographic analysis of the degassed nitrates has shown that impurities were less than $0.1 \%$. The nitrates were introduced into the flow reactor from a 10L flask containing nitrate-He mixture or by passing helium through a thermostated glass bubbler containing liquid nitrate and were detected by mass spectrometry at their fragment peaks at $m / z=76\left(\mathrm{CH}_{2} \mathrm{ONO}_{2}{ }^{+}\right)$, which were much more intensive than the parent ones. All other species were detected at their parent peaks: $\mathrm{m} / z=86$ (trimethylacetaldehyde $\left.\left(\left(\mathrm{CH}_{3}\right)_{3} \mathrm{CCHO}\right)^{+}\right), 160\left(\mathrm{Br}_{2}^{+}\right), 96 / 98\left(\mathrm{HOBr}^{+}\right), 46\left(\mathrm{NO}_{2}^{+}\right)$. The absolute concentrations of the nitrates as well as of other stable species in the reactor were calculated from their flow rates determined by measuring a pressure drop over time of their mixtures with helium from known volume flasks. Another method employed for the absolute calibration of mass spectrometer for nitrates consisted in injecting of the known volume of liquid nitrate inside the flow tube, and recording its mass peak intensity. The integrated area of the mass spectrometric signals corresponding to the known total number of nitrate molecules injected into the reactor allowed the determination of the calibration factor. Two methods of the determination of the absolute concentrations of nitrates, by measurements of 
their flow rates and direct injection of liquid nitrate in the reactor, were consistent within 10$15 \%$.

\section{Results}

\subsection{Measurements of the rate constants.}

Measurements of the rate constants of the reactions (1) - (3) were carried out under pseudo-first order conditions in excess of nitrates over $\mathrm{OH}$ radicals. Initial concentration of $\mathrm{OH}$ radicals was $(3-5) \times 10^{11}$ molecule $\mathrm{cm}^{-3}$, those of the nitrates are shown in Table 1 .

\section{Table 1}

Experimental Conditions and Results of the Measurements of the Rate Constants of Reactions $(1)-(3)$.

\begin{tabular}{|c|c|c|c|c|}
\hline$T(\mathrm{~K})$ & reactor surface ${ }^{a}$ & $\begin{array}{c}\text { number of } \\
\text { kinetic runs }\end{array}$ & $\begin{array}{c}\text { [nitrate] } \\
\left(10^{13} \text { molecule } \mathrm{cm}^{-3}\right) \\
\end{array}$ & $\begin{array}{c}k^{b} \\
\left(10^{-12} \mathrm{~cm}^{3} \text { molecule } \mathrm{s}^{-1}\right)\end{array}$ \\
\hline \multicolumn{5}{|c|}{$\mathrm{OH}+2$-methyl-1-butyl nitrate } \\
\hline 278 & HW & 6 & $3.56-13.8$ & 2.08 \\
\hline 288 & HW & 9 & $1.98-14.5$ & 2.09 \\
\hline 298 & HW & 8 & $1.71-8.14$ & 2.12 \\
\hline 318 & HW & 8 & $1.50-9.55$ & 2.14 \\
\hline 345 & HW & 8 & $1.22-11.1$ & 2.19 \\
\hline 455 & $\mathrm{Q}$ & 8 & $0.69-7.43$ & 2.98 \\
\hline 500 & Q & 9 & $1.14-8.69$ & 3.47 \\
\hline 538 & Q & 9 & $0.50-5.82$ & 4.15 \\
\hline \multicolumn{5}{|c|}{$\mathrm{OH}+$ neopentyl nitrate } \\
\hline 278 & HW & 6 & $0.32-1.54$ & 0.70 \\
\hline 288 & HW & 8 & $0.51-2.56$ & 0.72 \\
\hline 298 & HW & 6 & $0.24-1.69$ & 0.77 \\
\hline 318 & HW & 9 & $0.26-2.58$ & 0.81 \\
\hline 345 & HW & 9 & $0.31-2.39$ & 0.89 \\
\hline 455 & Q & 5 & $0.25-1.29$ & 1.49 \\
\hline 500 & Q & 8 & $0.08-1.08$ & 1.89 \\
\hline \multicolumn{5}{|c|}{$\mathrm{OH}+1$-hexyl nitrate } \\
\hline 306 & HW & 8 & $0.42-1.63$ & 3.89 \\
\hline 315 & HW & 8 & $0.40-2.94$ & 3.90 \\
\hline 318 & HW & 8 & $0.70-2.64$ & 3.83 \\
\hline 331 & HW & 7 & $0.36-2.21$ & 4.03 \\
\hline
\end{tabular}


9

${ }^{a}$ HW: halocarbon wax, Q: quartz.

${ }^{b}$ Estimated uncertainty on $k$ is nearly $15 \%$.

The flow velocity in the reactor was in the range $(840-1890) \mathrm{cm} \mathrm{s}^{-1}$. The concentrations of $\mathrm{OH}$ and nitrates were simultaneously monitored as a function of reaction time. The consumption of nitrates was unimportant as a result of their high excess over $\mathrm{OH}$ radicals and negligible wall loss. Examples of exponential decays of $\mathrm{OH}$ in reaction (1) in accordance with expression $[\mathrm{OH}]=[\mathrm{OH}]_{0} \times \exp \left(-k^{\prime} \times t\right)$ are shown in Fig. 1.

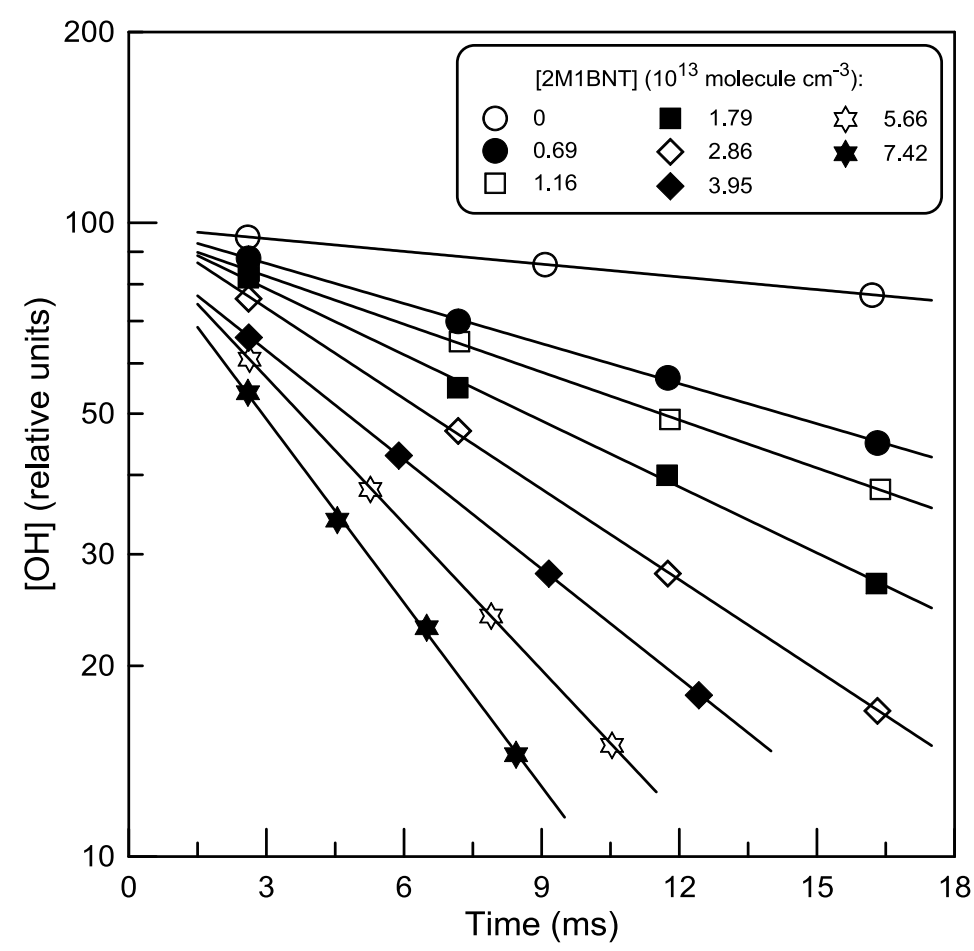

Fig. 1. Examples of the pseudo-first-order decays of $\mathrm{OH}$ in reaction with 2-methyl-1-butyl nitrate: $\mathrm{T}=455$ $\mathrm{K}$. Uncertainty on the measurements of the relative concentrations of $\mathrm{OH}(\leq 5 \%)$ corresponds to the size of the symbols.

Figs. 2 and S2 - S3 (Supplementary Data) show examples of the typical dependencies of the pseudo-first order rate constant, $k^{\prime}=k[$ nitrate $]+k_{\mathrm{w}}$, on concentration of the corresponding nitrate. $k_{\mathrm{w}}$ represents the rate of $\mathrm{OH}$ decay in the absence of nitrate in the reactor and was 
measured in separate experiments. All the measured values of $k^{\prime}$ were corrected for axial and radial diffusion of $\mathrm{OH}$ (Kaufman, 1984). The diffusion coefficient of $\mathrm{OH}$ in $\mathrm{He}$ was calculated using the following expression: $D_{0}=640 \times(\mathrm{T} / 298)^{1.85}$ Torr $\mathrm{cm}^{2} \mathrm{~s}^{-1}$ (Bedjanian et al., 2010; Ivanov et al., 2007). Corrections on $k^{\prime}$ were generally less than $10 \%$, however, in a few kinetic runs they were somewhat higher (up to 15\%). The slopes of the straight lines in Figs. 2 and S2 - S3 provide the values of the rate constants at respective temperatures. The intercepts were generally in agreement in the range of the experimental uncertainty with the corresponding $\mathrm{OH}$ loss rate measured in the absence of nitrates in the reactor: $k_{\mathrm{w}}$ was in the range $7-25 \mathrm{~s}^{-1}$ depending rather on state of the reactor surface than on temperature.

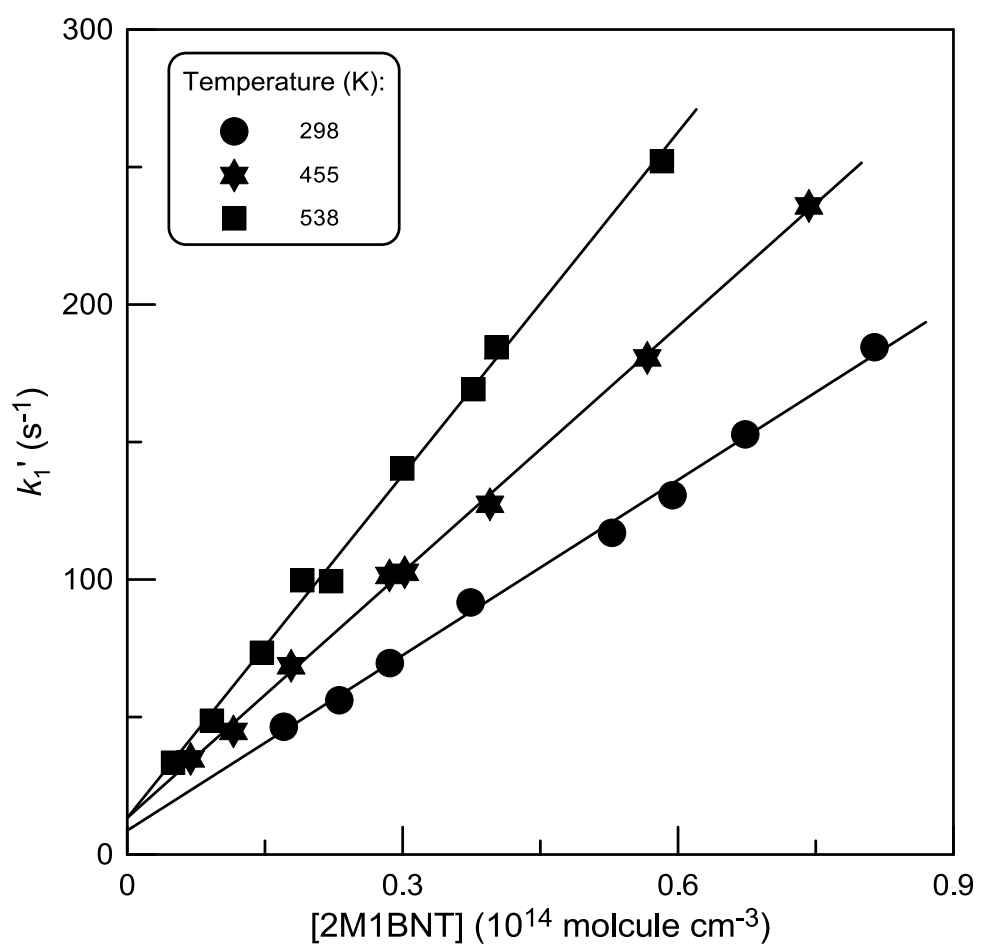

Fig. 2. Pseudo-first-order rate constant $\left(k_{1}{ }^{\prime}\right)$ as a function of the concentration of 2-methyl-1-butyl nitrate at $\mathrm{T}=298,455$ and $538 \mathrm{~K}$.

In order to check for the possible impact of a secondary chemistry on the results of the measurements, the rates of the $\mathrm{OH}+$ nitrate reactions were measured as a function of initial concentration of $\mathrm{OH}$ radicals. Fig. S4 (Supplementary Data) shows the results of the measurements of $k_{1}{ }^{\prime}$ at a fixed concentration of 2M1BNT and varied initial concentration of 
$\mathrm{OH}$. Independence of the reaction rate of the concentration of $\mathrm{OH}$ for $[\mathrm{OH}]_{0}<10^{12}$ molecule $\mathrm{cm}^{-3}$ indicates the negligible contribution of the secondary chemistry to $\mathrm{OH}$ loss under experimental conditions of the study $\left([\mathrm{OH}]_{0} \leq 5 \times 10^{11}\right.$ molecule $\left.\mathrm{cm}^{-3}\right)$. Similar behavior was observed for the reactions of OH with NPTNT and 1HXNT.

All the results obtained for the rate constants of reactions (1) - (3) at different temperatures are shown in Table 1 . The lowest temperature in the rate constant measurements in both low- and high temperature reactors was limited by impact of the heterogeneous chemistry which was manifested in an anomalous increase of the measured rate constant with decreasing temperature (Morin et al., 2015). Highest temperature of the study (500-540 K) was limited by thermal decomposition of the nitrates (Morin and Bedjanian, 2016, 2017a, b).

Temperature dependences of the rate constants of the reactions of $\mathrm{OH}$ with $2 \mathrm{M} 1 \mathrm{BNT}$, NPTNT and 1HXNT are shown in Figs. 3, 4 and 5, respectively. The combined uncertainty on the measurements of the rate constants was estimated to be nearly $15 \%$, by adding in quadrature the statistical error (within a few percent) and those on the measurements of the flows $(5 \%)$, pressure $(2 \%)$, temperature $(1 \%)$ and the absolute concentrations of the nitrates $(\sim$ $10 \%)$. One can note that the temperature dependence of the measured rate constants deviates from a simple Arrhenius behavior as could be expected considering that the overall rate constant is the sum of those for H-atom abstraction channels proceeding through breaking of different $\mathrm{C}-\mathrm{H}$ bonds. The experimental data were fitted with a three-parameter expression, leading to the following results (solid lines in Figs. 3 - 5):

$$
\begin{aligned}
& k_{1}=1.54 \times 10^{-14}(T / 298)^{4.85} \exp (1463 / \mathrm{T}) \mathrm{cm}^{3} \text { molecule }^{-1} \mathrm{~s}^{-1}(\mathrm{~T}=278-538 \mathrm{~K}), \\
& k_{2}=1.39 \times 10^{-14}(T / 298)^{4.89} \exp (1189 / \mathrm{T}) \mathrm{cm}^{3} \text { molecule }^{-1} \mathrm{~s}^{-1}(\mathrm{~T}=278-500 \mathrm{~K}) \\
& k_{3}=2.23 \times 10^{-13}(T / 298)^{2.83} \exp (853 / \mathrm{T}) \mathrm{cm}^{3} \text { molecule }^{-1} \mathrm{~s}^{-1}(\mathrm{~T}=306-538 \mathrm{~K}),
\end{aligned}
$$

with conservative independent of temperature $15 \%$ uncertainty on the rate constants. 


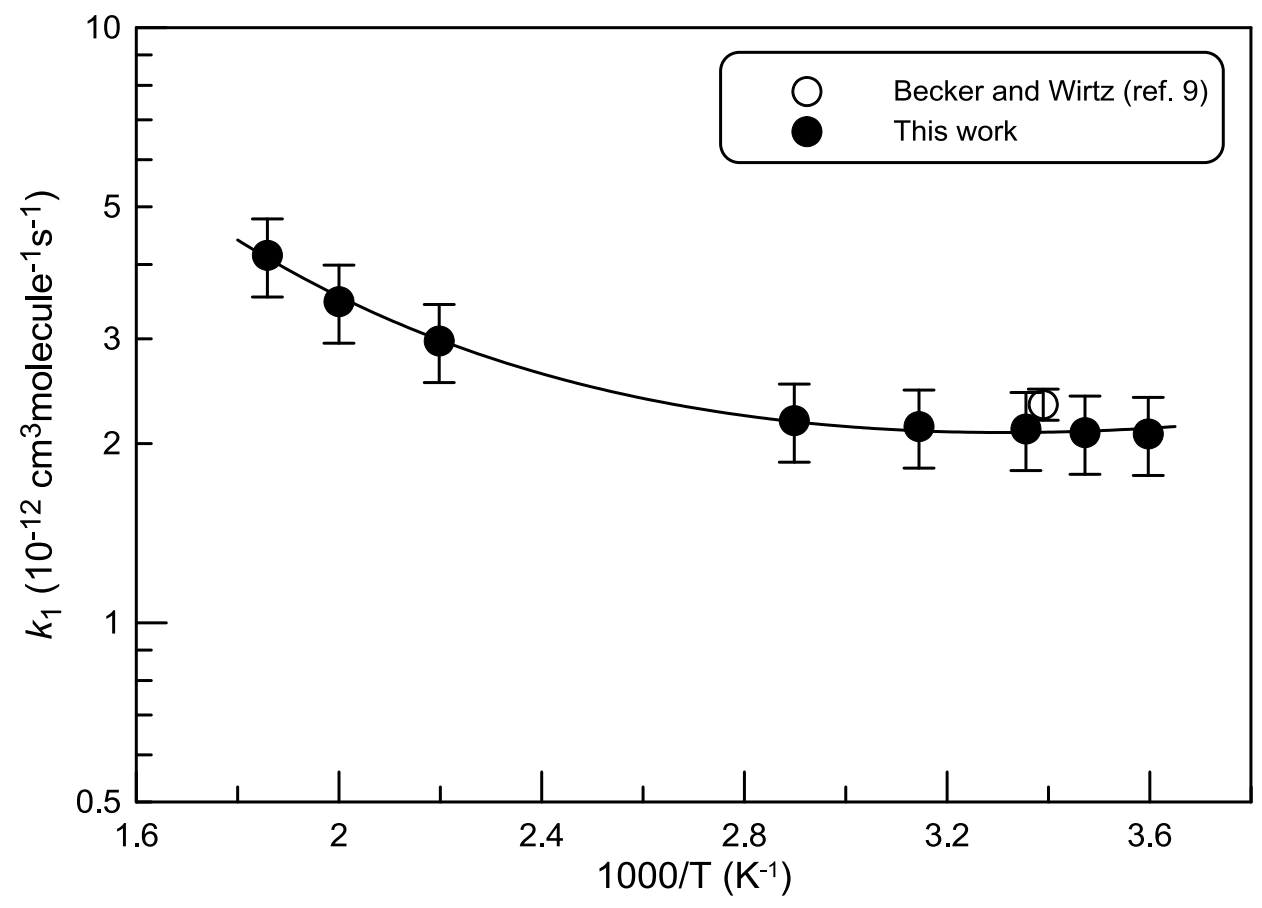

Fig. 3. Temperature dependence of the rate constant of the reaction $\mathrm{OH}+2$-methyl-1-butyl nitrate.

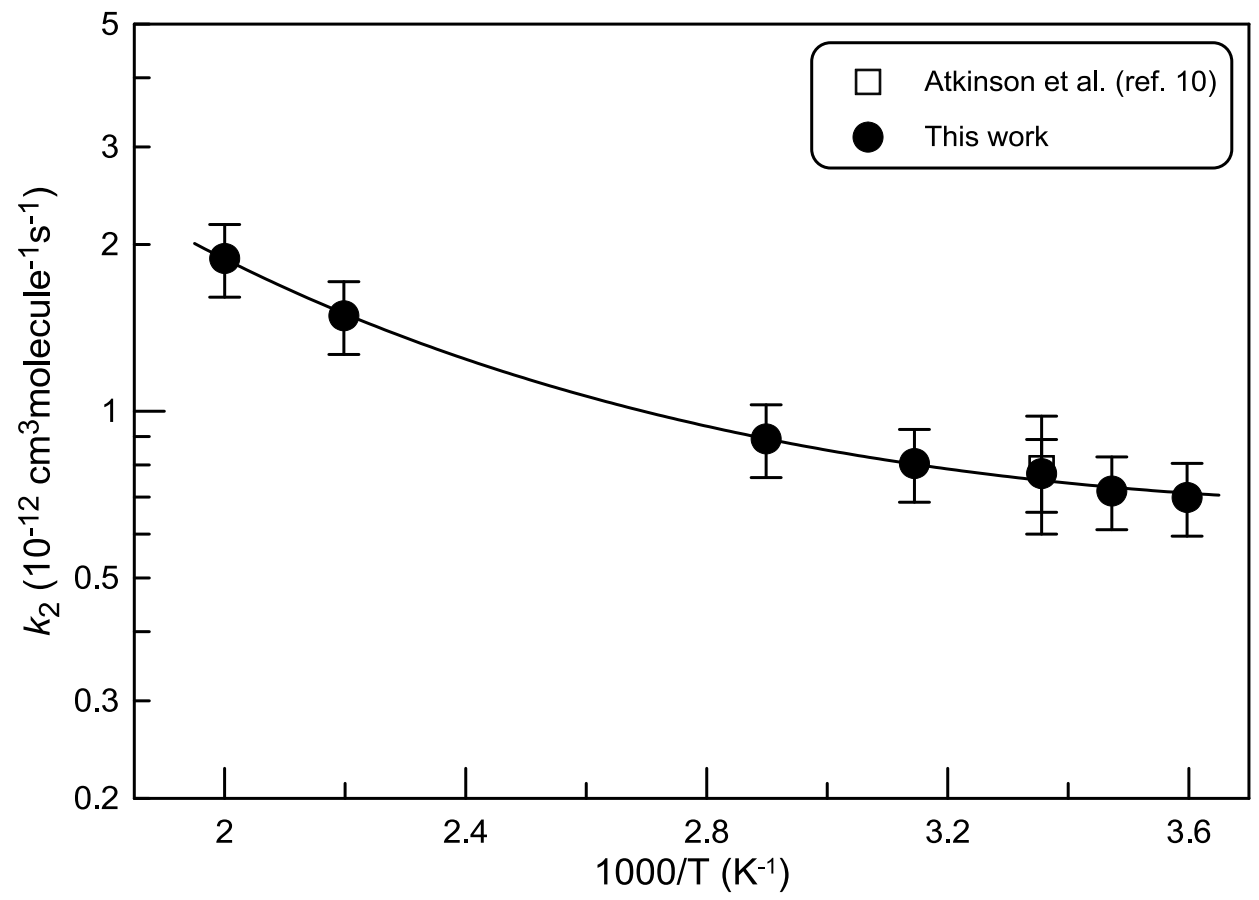

Fig. 4. Temperature dependence of the rate constant of the reaction $\mathrm{OH}+$ neopentyl nitrate. 


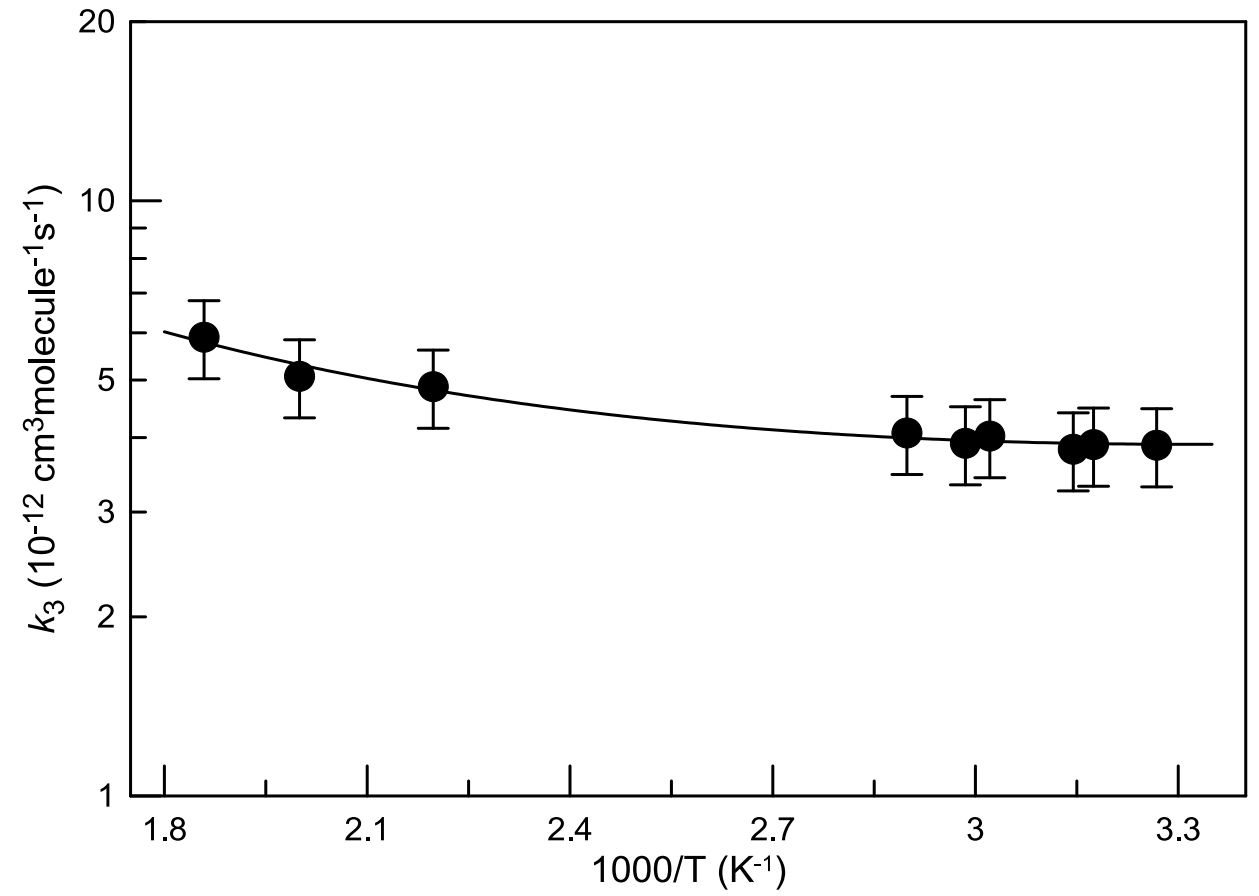

Fig. 5. Temperature dependence of the rate constant of the reaction $\mathrm{OH}+1$-hexyl nitrate.

\section{2. $\alpha$-hydrogen atom abstraction channel in reaction (2).}

Abstraction by $\mathrm{OH}$ of a hydrogen atom from $\alpha$-carbon in organic nitrates leads to the formation of an $\alpha$-substituted alkyl radicals:

$$
\mathrm{OH}+\mathrm{R}_{1} \mathrm{R}_{2} \mathrm{CHONO}_{2} \rightarrow \mathrm{R}_{1} \mathrm{R}_{2} \mathrm{C}^{\bullet} \mathrm{ONO}_{2}+\mathrm{H}_{2} \mathrm{O}
$$

These radicals are known to be unstable, dissociating spontaneously without an energetic barrier to form a carbonyl compound and $\mathrm{NO}_{2}$ (Vereecken, 2008):

$$
\mathrm{R}_{1} \mathrm{R}_{2} \mathrm{C}^{\bullet} \mathrm{ONO}_{2} \rightarrow \mathrm{R}_{1} \mathrm{R}_{2} \mathrm{C}=\mathrm{O}+\mathrm{NO}_{2}
$$

In this respect, the measurements of the yield of corresponding carbonyl compound provide the information on the extent of $\mathrm{H}$-atom abstraction from $\alpha$ carbon. In the present paper, we have determined at $\mathrm{T}=298 \mathrm{~K}$ the yield of trimethylacetaldehyde $\left(\left(\mathrm{CH}_{3}\right)_{3} \mathrm{CCHO}\right)$, resulting from the abstraction by $\mathrm{OH}$ of an $\alpha$-hydrogen atom in neopentyl nitrate followed by corresponding $\alpha$-substituted alkyl radical decomposition. The experiments on the determination of the yield of trimethylacetaldehyde in reaction 2 consisted in the monitoring of the consumed $[\mathrm{OH}]$ and $\left[\left(\mathrm{CH}_{3}\right)_{3} \mathrm{CCHO}\right]$ formed at a reaction time of $(7-28) \mathrm{ms}$. The 
concentration of neopentyl nitrate in these experiments was nearly $1.5 \times 10^{14}$ molecule $\mathrm{cm}^{-3}$ and $[\mathrm{OH}]$ was varied in the range $(0.23-1.27) \times 10^{12}$ molecule $\mathrm{cm}^{-3}$. Concentration of $\mathrm{OH}$ consumed in reaction with nitrate was determined as a difference between initial concentration of the radicals (measured in the absence of the nitrate and presence of $\mathrm{Br}_{2}$ in the main reactor) and concentration of $\mathrm{OH}$ recorded in the presence of the nitrate in the reactor $\left(\mathrm{Br}_{2}\right.$ being added at the end of the reactor). The relative contribution of the wall loss to consumed $[\mathrm{OH}]$ was $\leq 10 \%$ in these experiments and was taken into account. The experimental data are shown in Fig. 6.

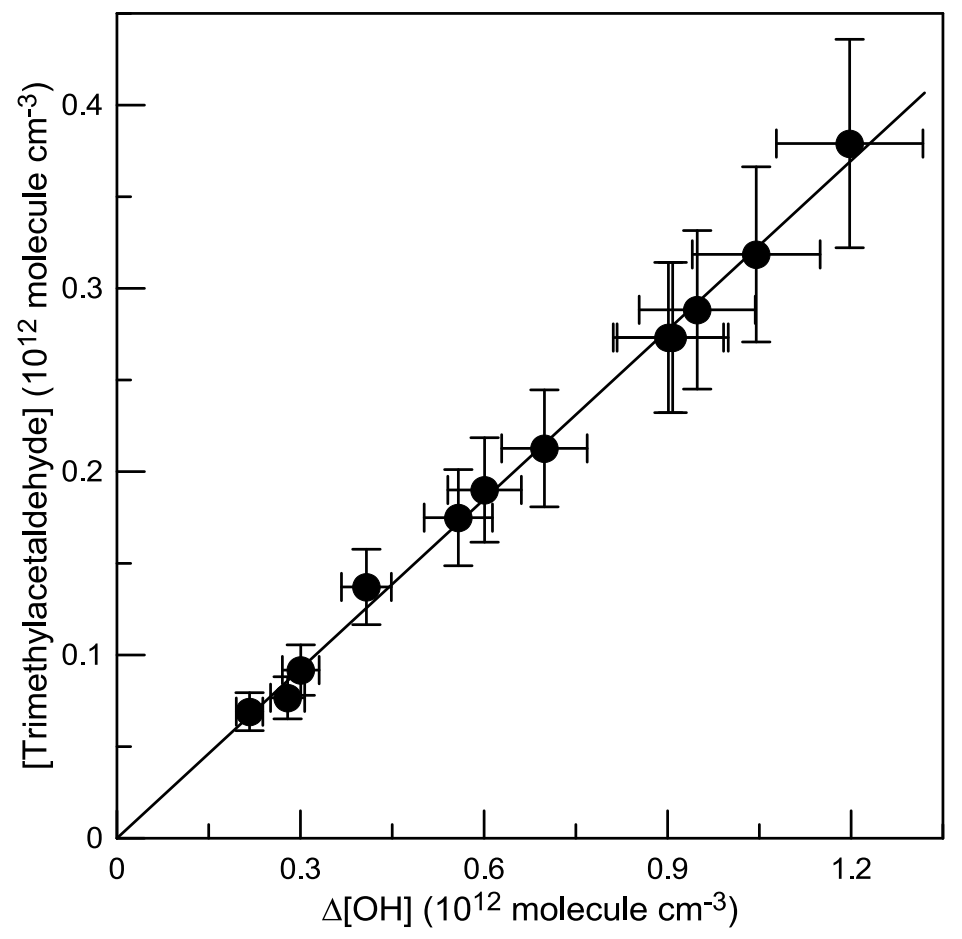

Fig. 6. Concentration of trimethylacetaldehyde formed in reaction 2 as a function of the consumed concentration of $\mathrm{OH}$.

Error bars in Figures 6 correspond to $10 \%$ and $15 \%$ uncertainties on the measurements of the concentrations of $\mathrm{OH}$ and trimethylacetaldehyde, respectively. Higher uncertainty on the measurements of the concentrations of trimethylacetaldehyde is due to important contribution to its parent peak at $\mathrm{m} / \mathrm{z}=86$ of neopentyl nitrate upon its fragmentation in the ion source of the mass spectrometer which was operated at 25-30 eV energy. The contribution of neopentyl 
nitrate was directly monitored in the absence of $\mathrm{OH}$ in the reactive system (discharge off) and was extracted from the signal at $\mathrm{m} / \mathrm{z}=86$ observed in reaction $\mathrm{OH}+$ neopentyl nitrate (discharge on). The slope of the straight line in Fig. 6 provides the yield of trimethylacetaldehyde in reaction $(2)$ at $\mathrm{T}=298 \mathrm{~K}: 0.31 \pm 0.06$. The estimated nearly $20 \%$ uncertainty on the determination of the yield arises mainly from the combined errors on the measurements of the concentrations of $\mathrm{OH}$ and the reaction product.

\section{Discussion}

\subsection{Comparison with previous studies and atmospheric implications.}

To our knowledge, this is the first study of the reaction of $\mathrm{OH}$ radicals with 1-hexyl nitrate and the first measurement of the temperature dependence of the rate constant of the $\mathrm{OH}$ reactions with 2-methyl-1-butyl and neopentyl nitrates. The rate constants of the reactions 1 and $2, k_{1}=(2.33 \pm 0.14) \times 10^{-12}$ and $k_{2}=(0.79 \pm 0.19) \times 10^{-12} \mathrm{~cm}^{3}$ molecule $\mathrm{s}^{-1}$ measured by Becker and Wirtz (1989) at $\mathrm{T}=295$ and Atkinson et al. (1984) at $\mathrm{T}=298 \mathrm{~K}$, respectively, using relative rate method and placed on an absolute basis in (Calvert et al., 2011) using new recommendation for the reference reaction $\mathrm{OH}+n$-butane, agree in the range of the reported experimental uncertainties with the present data (Figs. 3 and 4). The consistency in rate coefficients measured in previous studies at 1 atm total pressure and those from the present study in 1 Torr of helium is expected for a bimolecular reaction proceeding via $\mathrm{H}$-atom abstraction.

In this study, we have determined at $\mathrm{T}=298 \mathrm{~K}$ the yield of trimethylacetaldehyde resulting from the decomposition of $\alpha$-substituted alkyl radicals formed upon initial abstraction by $\mathrm{OH}$ of an $\alpha$-hydrogen atom in neopentyl nitrate. The measured product yield can be considered as the branching ratio for an $\alpha$-hydrogen atom abstraction pathway:

$$
\mathrm{OH}+\left(\mathrm{CH}_{3}\right)_{3} \mathrm{CCH}_{2} \mathrm{ONO}_{2} \rightarrow\left(\mathrm{CH}_{3}\right)_{3} \mathrm{CCHONO}_{2}+\mathrm{H}_{2} \mathrm{O}
$$




$$
k_{2 \mathrm{a}} / k_{2}=0.31 \pm 0.06
$$

The major atmospheric sinks of alkyl nitrates are their UV photolysis and reactions with $\mathrm{OH}$ radicals. The tropospheric lifetimes of 2M1BNT, NPTNT and 1HXNT, with respect to their loss via reaction with $\mathrm{OH}$, calculated using the measured rate constants (at $\mathrm{T}=298 \mathrm{~K}$ ) and a $24 \mathrm{~h}$ average concentration of $\mathrm{OH}$ radical of $10^{6}$ molecules $\mathrm{cm}^{-3}$, are $5.5,15$ and 3 days, respectively. The gas-phase ultraviolet absorption cross-sections of 2M1BNT, NPTNT and 1HXNT are not known. However, under assumption that the tropospheric lifetimes of these compounds with respect to their photolysis are close to those reported by Clemitshaw et al. (1997) for several $\mathrm{C}_{2}-\mathrm{C}_{5}$ alkyl nitrates (between 3 and 13 days for summer conditions, depending on altitude $(0-10 \mathrm{~km})$ and latitude $\left.\left(0-60^{\circ} \mathrm{N}\right)\right)$, reaction with $\mathrm{OH}$ radicals is an important atmospheric sink for the alkyl nitrates considered in the present study, comparable with that due to their photolysis.

4.2. Reactivity of alkyl nitrates with $\mathrm{OH}$ : trends and updated structure-activity relationship $(S A R)$

In our recent work (including the present study) (Bedjanian et al., 2017; Morin et al., 2016; Romanias et al., 2015) we have measured temperature dependence of the rate constant of the reaction of $\mathrm{OH}$ radicals with ten alkyl nitrates, for eight of them for the first time. The rate coefficients for the reactions of the ten alkyl nitrates with $\mathrm{OH}$ radicals determined at $\mathrm{T}=$ $298 \mathrm{~K}$ are shown in Table 2 together with the data for the reaction of $\mathrm{OH}$ with other alkyl nitrates available in the literature.

\section{Table 2}

Comparison of the Experimental and Calculated (within SAR) Rate Constants for Reactions of Alkyl Nitrates with $\mathrm{OH}$ at $\mathrm{T}=298 \mathrm{~K}$.

\begin{tabular}{|c|c|c|c|c|c|}
\hline Nitrate $^{a}$ & $k_{\exp }^{b}$ & $\begin{array}{c}k_{\mathrm{calc}}{ }^{b, c} \\
\text { (current SAR) }\end{array}$ & $\begin{array}{c}k_{\text {calc }} / k_{\exp } \\
(\text { current SAR) }\end{array}$ & $\begin{array}{l}k_{\text {calc }}^{b, d} \\
\text { (this work) }\end{array}$ & $\begin{array}{c}k_{\text {calc }} / k_{\text {exp }} \\
\text { (this work) }\end{array}$ \\
\hline
\end{tabular}




\begin{tabular}{|c|c|c|c|c|c|}
\hline MNT & $0.23^{e}$ & 0.05 & 0.22 & 0.19 & 0.83 \\
\hline ENT & $2.01^{f}$ & 0.65 & 0.32 & 1.69 & 0.84 \\
\hline PNT & $5.98^{f}$ & 4.00 & 0.67 & 5.90 & 0.99 \\
\hline IPNT & $3.02^{f}$ & 1.32 & 0.44 & 3.48 & 1.15 \\
\hline $1 \mathrm{BNT}$ & $16.6^{f}$ & 15.9 & 0.96 & 18.0 & 1.08 \\
\hline IBNT & $12.3^{f}$ & 7.69 & 0.63 & 10.4 & 0.85 \\
\hline 1PNNT & $30.9^{f}$ & 30.0 & 0.97 & 32.1 & 1.04 \\
\hline IPNNT & $30.6^{f}$ & 30.0 & 0.98 & 32.0 & 1.05 \\
\hline NPTNT & $7.51^{f}$ & 5.48 & 0.73 & 6.63 & 0.88 \\
\hline 2M1BNT & $20.9^{f}$ & 20.1 & 0.96 & 23.1 & 1.11 \\
\hline 1HXNT & $39.0^{f}$ & 44.2 & 1.13 & 46.2 & 1.18 \\
\hline 2BNT & $8.60^{e}$ & 4.77 & 0.55 & 8.01 & 0.93 \\
\hline 2PNNT & $17.2^{g}$ & 16.7 & 0.97 & 20.1 & 1.17 \\
\hline 3PNNT & $10.4^{g}$ & 8.26 & 0.79 & 12.7 & 1.22 \\
\hline $3 \mathrm{M} 2 \mathrm{BNT}$ & $17.0^{g}$ & 8.45 & 0.50 & 12.5 & 0.74 \\
\hline 2HXNT & $29.4^{g}$ & 30.8 & 1.05 & 34.2 & 1.16 \\
\hline 3HXNT & $25.0^{g}$ & 20.2 & 0.81 & 24.8 & 0.99 \\
\hline 2M2PNNT & $15.9^{g}$ & 16.0 & 1.01 & 17.1 & 1.08 \\
\hline $3 \mathrm{M} 2 \mathrm{PNNT}$ & $28.0^{g}$ & 20.8 & 0.74 & 25.2 & 0.90 \\
\hline 3HPTNT & $34.2^{g}$ & 34.3 & 1.00 & 38.9 & 1.14 \\
\hline 3OCTNT & $36.0^{g}$ & 48.4 & 1.34 & 53.0 & 1.47 \\
\hline
\end{tabular}

${ }^{a}$ Chemical names and formula corresponding to the abbreviations are listed in Table S1 (Supplementary Data).

${ }^{b}$ Units of $10^{-13} \mathrm{~cm}^{3}$ molecule ${ }^{-1} \mathrm{~s}^{-1}$.

${ }^{c}$ Calculated with $F\left(-\mathrm{ONO}_{2}\right)=0.04$ and $F\left(-\mathrm{CH}_{2} \mathrm{ONO}_{2}\right)=F\left(>\mathrm{CHONO}_{2}\right)=F\left(\equiv \mathrm{C}-\mathrm{ONO}_{2}\right)=0.20(\mathrm{Kwok}$ and Atkinson, 1995).

${ }^{d}$ Calculated with $F\left(-\mathrm{ONO}_{2}\right)=0.14$ and $F\left(-\mathrm{CH}_{2} \mathrm{ONO}_{2}\right)=F\left(>\mathrm{CHONO}_{2}\right)=F\left(\equiv \mathrm{C}-\mathrm{ONO}_{2}\right)=0.28$ (this work).

${ }^{e}$ Atkinson et al. (2006).

${ }^{f}$ Data from this group ((Bedjanian et al., 2017; Morin et al., 2016; Romanias et al., 2015) and this work)

${ }^{g}$ Data from (Atkinson et al., 1982; Atkinson et al., 1984; Becker and Wirtz, 1989) updated by Calvert et al. (2011).

For six alkyl nitrates, reaction products corresponding to direct recycling of $\mathrm{NO}_{2}(\alpha$-hydrogen atom abstraction channel) were observed and their yield measured (Table 3) ((Bedjanian et al., 2017; Morin et al., 2016; Morin et al., 2015) and this study).

\section{Table 3}

Comparison of the experimental and calculated (within SAR) branching ratios for $\mathrm{H}$-atom abstraction from $\alpha$ carbon $\left(k_{\alpha} / k_{\text {total }}\right)$ in reactions of alkyl nitrates with $\mathrm{OH}$ at $\mathrm{T}=298 \mathrm{~K}$.

\begin{tabular}{|c|c|c|c|c|c|}
\hline \multirow[b]{2}{*}{ nitrate } & \multicolumn{5}{|c|}{$k_{\alpha} / k_{\text {total }}$} \\
\hline & $\exp ^{a}$ & $\begin{array}{c}\text { calc. }^{b} \\
\text { (current SAR) }\end{array}$ & $\begin{array}{c}\text { calc./exp. } \\
\text { (current SAR) }\end{array}$ & $\begin{array}{c}\text { calc. }^{c} \\
\text { (this work ) }\end{array}$ & $\begin{array}{l}\text { calc./exp. } \\
\text { (this work) }\end{array}$ \\
\hline
\end{tabular}




\begin{tabular}{llllll}
\hline ENT & 0.77 & 0.58 & 0.75 & 0.77 & 1.00 \\
PNT & 0.22 & 0.11 & 0.50 & 0.27 & 1.23 \\
IPN & 0.82 & 0.59 & 0.72 & 0.78 & 0.95 \\
IBNT & 0.10 & 0.03 & 0.30 & 0.09 & 0.90 \\
IBNT & 0.15 & 0.06 & 0.40 & 0.15 & 1.00 \\
NPTNT & 0.31 & 0.08 & 0.26 & 0.24 & 0.77 \\
\hline
\end{tabular}

${ }^{a}$ Experimental data from (Bedjanian et al., 2017; Morin et al., 2016; Romanias et al., 2015) and present work.

${ }^{b}$ Calculated with $F\left(-\mathrm{ONO}_{2}\right)=0.04$ and $F\left(-\mathrm{CH}_{2} \mathrm{ONO}_{2}\right)=F\left(>\mathrm{CHONO}_{2}\right)=F\left(\equiv \mathrm{C}-\mathrm{ONO}_{2}\right)=0.20($ Kwok and Atkinson, 1995).

${ }^{c}$ Calculated with $F\left(-\mathrm{ONO}_{2}\right)=0.14$ and $F\left(-\mathrm{CH}_{2} \mathrm{ONO}_{2}\right)=F\left(>\mathrm{CHONO}_{2}\right)=F\left(\equiv \mathrm{C}-\mathrm{ONO}_{2}\right)=0.28$ (this work).

The results of kinetic and mechanistic studies from our group support the previous conclusions (Calvert et al., 2011) on the trends in the reactivity of alkyl nitrates toward $\mathrm{OH}$ radicals: (i) reactions proceed through $\mathrm{H}$-atom abstraction channel; (ii) the reactivity increases with the length of alkyl chain, as one could expect, due to increasing number of $\mathrm{CH}_{2}$ groups and their distance from the deactivating nitrate group; (iii) $n$-alkyl nitrates are more reactive than corresponding iso-alkyl nitrates, as one could expect considering increase in reactivity from $\mathrm{CH}_{3}$ to $\mathrm{CH}_{2}$ and to $\mathrm{CH}$ group; (iv) curved temperature dependencies of the rate constants observed in our studies at elevated temperatures seem to reflect simultaneous occurrence of primary, secondary and tertiary $\mathrm{H}$-atom abstraction pathways.

Based on the rate constants measured in our group and those available in the literature (Table 2) we attempted an update of structure-activity relationship for reactions of alkyl nitrates with $\mathrm{OH}$ at $\mathrm{T}=298 \mathrm{~K}$. The employed procedure was similar to that of $\mathrm{Kwok}$ and Atkinson (1995). A nonlinear least-squares analysis of the rate constant data was performed with two variable parameters, substituent factors $F\left(-\mathrm{ONO}_{2}\right)$ and $F\left(-\mathrm{CH}_{2} \mathrm{ONO}_{2}\right)=$ $F\left(>\mathrm{CHONO}_{2}\right)=F\left(\equiv \mathrm{C}-\mathrm{ONO}_{2}\right)$, minimizing $\left(\left(k_{\text {exp }}-k_{\text {calc }}\right) / k_{\text {exp }}\right)^{2}$, where $k_{\text {exp }}$ and $k_{\text {calc }}$ are the experimental and calculated (within SAR) rate constants, respectively. In the analysis, the branching ratios for $\mathrm{H}$-atom abstraction from $\alpha$ carbon measured in this group $\left(\left(k_{\alpha} / k_{\text {total }}\right)\right.$ in Table 3) were also included. The used group rate constants for abstraction of primary, 
secondary, and tertiary $\mathrm{H}$-atoms and other substituent factors were those from Kwok and Atkinson (1995): $k\left(-\mathrm{CH}_{3}\right)=0.136, k\left(-\mathrm{CH}_{2}-\right)=0.934$ and $k(>\mathrm{CH}-)=1.94 \times 10^{-12} \mathrm{~cm}^{3}$ molecule ${ }^{-}$ ${ }^{1} \mathrm{~s}^{-1} ; F\left(-\mathrm{CH}_{3}\right)=1, F\left(-\mathrm{CH}_{2}-\right)=F(>\mathrm{CH}-)=F(>\mathrm{C}<)=0.23$. The best agreement between measured and calculated rate constants was achieved with the following substituent factors: $F\left(-\mathrm{ONO}_{2}\right)=0.14$ and $F\left(-\mathrm{CH}_{2} \mathrm{ONO}_{2}\right)=F\left(>\mathrm{CHONO}_{2}\right)=F\left(\equiv \mathrm{C}-\mathrm{ONO}_{2}\right)=0.28$. One can state an excellent agreement (within a factor of nearly 1.2, which is equivalent to the precision of experimental measurements) between the calculated (using these substituents factors) and experimentally measured rate constants (Table 2 and Fig. 7), for all the experimental data available except two compounds (3M2BNT and 3OCTNT). The calculated branching ratios for the $\mathrm{H}$-atom abstraction from $\alpha$ carbon are also in good agreement with the experimental data (Table 3). The rate constants calculated with substituent factors derived previously (Kwok and Atkinson, 1995) significantly deviate from the experimental values, particularly for small nitrates (Table 2), and reproduce very poorly the branching ratio data (Table 3). Difficulties arising for the prediction of the rate constants of $\mathrm{OH}$ reactions with organic nitrates were also highlighted in a more recent development of SAR (Neeb, 2000). Considering an excellent agreement between experimental data and those calculated within SAR updated in the present work, the improved SAR can be, potentially, employed for calculations of the total rate constants and primary products of the reactions of $\mathrm{OH}$ with alkyl nitrates that have not yet been studied experimentally, and to predict, in this way, the atmospheric lifetime and first steps of the oxidation mechanism of these important atmospheric compounds. 


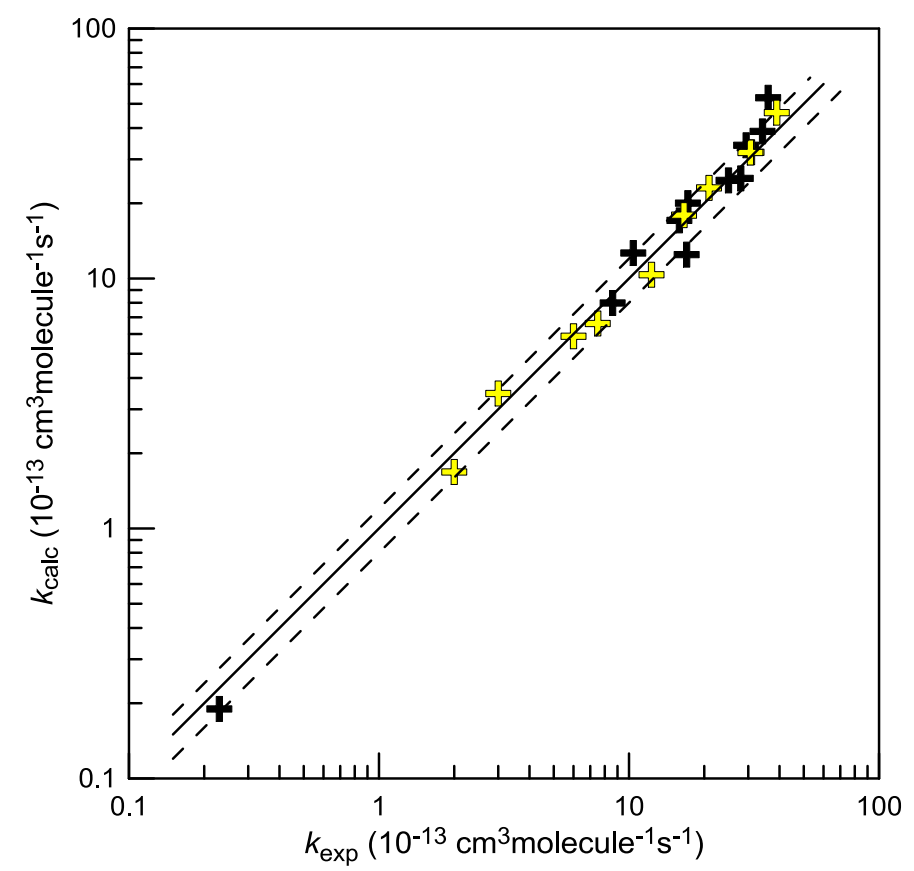

Fig. 7. Comparison of measured with calculated rate constants for reactions of alkyl nitrates with $\mathrm{OH}$ radicals at $\mathrm{T}=298 \mathrm{~K}$. The solid and dashed lines represent 1:1 and $(1 \pm 0.2): 1$ correlations, respectively. Yellow symbols represent experimental data from this group.

It should be emphasized that the updated estimation method is applicable only to alkyl nitrates and does not adequately describe the rate constants of $\mathrm{OH}$ reactions with multifunctional organic nitrates. Multifunctional organic nitrates are low-volatile and highly soluble and thus can be partitioned to the atmospheric condensed phases (droplets, aerosols) (Nah et al., 2016). Recent field observations have shown that organic nitrates can represent a large fraction of ambient submicron organic aerosols (Lee et al., 2016; Xu et al., 2015). Assessment of the atmospheric fate of multifunctional organic nitrates and their impact on aerosols composition and properties requires a good knowledge of their reactivity in gas and condensed phases. In this respect, future detailed studies of the reactivity of functionalized organic nitrates towards $\mathrm{OH}$ radicals would be of great interest to atmospheric science.

\section{Conclusion}

In this work, temperature dependencies of the rate constants of the atmospheric reactions of $\mathrm{OH}$ radicals with three alkyl nitrates, 2-methyl-1-butyl, neopentyl and 1- 
hexyl, were measured for the first time. The yield of trimethylacetaldehyde $\left(\left(\mathrm{CH}_{3}\right)_{3} \mathrm{CCHO}\right)$, resulting from the abstraction by $\mathrm{OH}$ of an $\alpha$-hydrogen atom in neopentyl nitrate, followed by $\alpha$-substituted alkyl radical decomposition, was determined as $0.31 \pm 0.06$ at $\mathrm{T}=298 \mathrm{~K}$. Tropospheric lifetimes of the three nitrates, calculated using the measured rate constants, indicate that reaction of these nitrates with $\mathrm{OH}$ represents an important sink of these compounds in the atmosphere. Using kinetic data from this study and those available in the literature, we have updated the structure-activity relationship (SAR) for reactions of alkyl nitrates with $\mathrm{OH}$ at $\mathrm{T}=298$ K. The updated SAR allows to reproduce the experimental rate constants of the reactions of $\mathrm{OH}$ with alkyl nitrates with rather high precision, and can be used to predict the total rate constants and products of the reactions of $\mathrm{OH}$ with alkyl nitrates, i.e. to estimate the atmospheric lifetime and anticipate the first steps of the oxidation mechanism of these important atmospheric species.

\section{Acknowledgement}

This work was supported by French National Research Agency (ANR) through project

ONCEM (ANR-12-BS06-0017-02). J. M. is very grateful for his $\mathrm{PhD}$ grant from CAPRYSSES project (ANR-11-LABX-006-01) funded by ANR through the PIA (Programme d'Investissement d'Avenir).

\section{Appendix A. Supplementary data}

Supplementary data related to this article can be found at ... 


\section{References}

Atkinson R., Aschmann S.M., Carter W.P.L., Winer A.M., 1982. Kinetics of the gas-phase reactions of $\mathrm{OH}$ radicals with alkyl nitrates at $299 \pm 2$ K. Int. J. Chem. Kinet. 14, 919926.

Atkinson R., Aschmann S.M., Carter W.P.L., Winer A.M., Pitts J.N., 1984. Formation of alkyl nitrates from the reaction of branched and cyclic alkyl peroxy radicals with NO. Int. J. Chem. Kinet. 16, 1085-1101.

Atkinson R., Baulch D.L., Cox R.A., Crowley J.N., Hampson R.F., Hynes R.G., Jenkin M.E., Rossi M.J., Troe J., 2006. Evaluated kinetic and photochemical data for atmospheric chemistry: Volume II - gas phase reactions of organic species. Atmos. Chem. Phys. 6, $3625-4055$.

Becker K.H., Wirtz K., 1989. Gas phase reactions of alkyl nitrates with hydroxyl radicals under tropospheric conditions in comparison with photolysis. J. Atmos. Chem. 9, 419433.

Bedjanian Y., Le Bras G., Poulet G., 1999a. Kinetic Study of OH + OH and OD + OD Reactions. J. Phys. Chem. A 103, 7017-7025.

Bedjanian Y., Le Bras G., Poulet G., 1999b. Kinetic Study of the Reactions of $\mathrm{Br}_{2}$ with OH and OD. Int. J. Chem. Kinet. 31, 698-704.

Bedjanian Y., Morin J., Romanias M.N., 2017. Kinetics of the reactions of OH radicals with n-butyl, isobutyl, n-pentyl and 3-methyl-1-butyl nitrates. Atmos. Environ. 155, 29-34.

Bedjanian Y., Nguyen M.L., Le Bras G., 2010. Kinetics of the Reactions of Soot SurfaceBound Polycyclic Aromatic Hydrocarbons with the OH Radicals. Atmos. Environ. 44, 1754-1760.

Boschan R., Merrow R.T., van Dolah R.W., 1955. The Chemistry of Nitrate Esters. Chem. Rev. 55, 485-510.

Calvert J., Mellouki A., Orlando J., Pilling M., Wallington T., 2011. Mechanisms of Atmospheric Oxidation of the Oxygenates. Oxford University Press, New York.

Clemitshaw K.C., Williams J., Rattigan O.V., Shallcross D.E., Law K.S., Anthony Cox R., 1997. Gas-phase ultraviolet absorption cross-sections and atmospheric lifetimes of several $\mathrm{C}_{2}-\mathrm{C}_{5}$ alkyl nitrates. J. Photochem. Photobio. A 102, 117-126.

Finlayson-Pitts B.J., Pitts J.N.J., 2000. Chemistry of the Upper and Lower Atmosphere: Theory, Experiments and Applications. Academic Press, San Diego, 969 pp. 
Ivanov A.V., Trakhtenberg S., Bertram A.K., Gershenzon Y.M., Molina M.J., 2007. OH, $\mathrm{HO}_{2}$, and Ozone Gaseous Diffusion Coefficients. J. Phys. Chem. A 111, 1632-1637.

Kaufman F., 1984. Kinetics of Elementary Radical Reactions in the Gas Phase. J. Phys. Chem. 88, 4909-4917.

Kwok E.S.C., Atkinson R., 1995. Estimation of Hydroxyl Radical Reaction Rate Constants for Gas-Phase Organic Compounds Using a Structure- Reactivity Relationship: an Update. Atmos. Environ. 29, 1685-1695.

Lee B.H. et al., 2016. Highly functionalized organic nitrates in the southeast United States: Contribution to secondary organic aerosol and reactive nitrogen budgets. Proceedings of the National Academy of Sciences 113, 1516-1521.

Morin J., Bedjanian Y., 2016. Thermal Decomposition of Isopropyl Nitrate: Kinetics and Products. J. Phys. Chem. A 120, 8037-8043.

Morin J., Bedjanian Y., 2017a. Kinetic and Mechanistic Study of the Thermal Decomposition of Ethyl Nitrate. Int. J. Chem. Kinet. 49, 354-362.

Morin J., Bedjanian Y., 2017b. Thermal decomposition of n-propyl and n-butyl nitrates: Kinetics and products. J. Anal. Appl. Pyrolysis 124, 576-583.

Morin J., Bedjanian Y., Romanias M.N., 2016. Kinetics and Products of the Reactions of Ethyl and n-Propyl Nitrates with OH Radicals. Int. J. Chem. Kinet. 48, 822-829.

Morin J., Romanias M.N., Bedjanian Y., 2015. Experimental Study of the Reactions of OH Radicals with Propane, n-Pentane, and n-Heptane over a Wide Temperature Range. Int. J. Chem. Kinet. 47, 629-637.

Nah T., Sanchez J., Boyd C.M., Ng N.L., 2016. Photochemical Aging of $\alpha$-pinene and $\beta$ pinene Secondary Organic Aerosol formed from Nitrate Radical Oxidation. Env. Scie. Tech. 50, 222-231.

Neeb P., 2000. Structure-Reactivity Based Estimation of the Rate Constants for Hydroxyl Radical Reactions with Hydrocarbons. J. Atmos. Chem. 35, 295-315.

Romanias M.N., Morin J., Bedjanian Y., 2015. Experimental Study of the Reaction of Isopropyl Nitrate with OH Radicals: Kinetics and Products. Int. J. Chem. Kinet. 47, 42-49.

Talukdar R.K., Burkholder J.B., Hunter M., Gilles M.K., Roberts J.M., Ravishankara A.R., 1997a. Atmospheric Fate of Several Alkyl Nitrates. Part 2 - UV Absorption CrossSections and Photodissociation Quantum Yields. J. Chem. Soc., Faraday Trans. 93, 2797-2805. 
Talukdar R.K., Herndon S.C., Burkholder J.B., Roberts J.M., Ravishankara A.R., 1997b. Atmospheric fate of several alkyl nitrates. Part 1 - Rate coefficients of the reactions of alkyl nitrates with isotopically labelled hydroxyl radicals. J. Chem. Soc., Faraday Trans. 93, 2787-2796.

Vereecken L., 2008. Computational study of the stability of $\alpha$-nitroxy-substituted alkyl radicals. Chem. Phys. Lett. 466, 127-130.

Xu L., Suresh S., Guo H., Weber R.J., Ng N.L., 2015. Aerosol characterization over the southeastern United States using high-resolution aerosol mass spectrometry: spatial and seasonal variation of aerosol composition and sources with a focus on organic nitrates. Atmos. Chem. Phys. 15, 7307-7336. 


\title{
Reactions of $\mathrm{OH}$ Radicals with 2-Methyl-1-Butyl, Neopentyl and 1-Hexyl
}

Nitrates. Structure-Activity Relationship for Gas-Phase Reactions of OH with Alkyl Nitrates: an Update

\author{
Yuri Bedjanian, Julien Morin, Manolis N. Romanias
}

Institut de Combustion, Aérothermique, Réactivité et Environnement (ICARE), CNRS and Université d'Orléans, 45071 Orléans Cedex 2, France

\section{Highlights}

- Rate constants of $\mathrm{OH}$ reactions with three alkyl nitrates are measured as a function of temperature

- Branching ratios for an $\alpha$-hydrogen atom abstraction in neopenthyl nitrate is measured

- Tropospheric lifetimes of the nitrates with respect to their reaction with $\mathrm{OH}$ are determined

- An updated structure-activity relationship (SAR) for reactions of alkyl nitrates with $\mathrm{OH}$ is proposed 


\title{
Supplementary Data
}

\section{Reactions of $\mathrm{OH}$ Radicals with 2-Methyl-1-Butyl, Neopentyl and 1-Hexyl Nitrates. Structure-Activity Relationship for Gas-Phase Reactions of $\mathrm{OH}$ with Alkyl Nitrates: an Update}

\author{
Yuri Bedjanian, ${ }^{*}$ Julien Morin, ${ }^{1}$ Manolis N. Romanias ${ }^{2}$ \\ Institut de Combustion, Aérothermique, Réactivité et Environnement (ICARE), CNRS and \\ Université d'Orléans, 45071 Orléans Cedex 2, France
}

Number of pages (including this one): $\quad 4$

Number of Figures: $\quad 4$

Number of Tables: $\quad 1$

\footnotetext{
* Corresponding author. CNRS/ICARE, , 45071 Orléans Cedex 2, France.

E-mail: yuri.bedjanian@cnrs-orleans.fr (Y. Bedjanian)

${ }^{1}$ Now at Aix Marseille Universite, CNRS, LCE, 13331, Marseille, France.

${ }^{2}$ Now at IMT Lille Douai, SAGE, F-59508, Douai, France.
} 


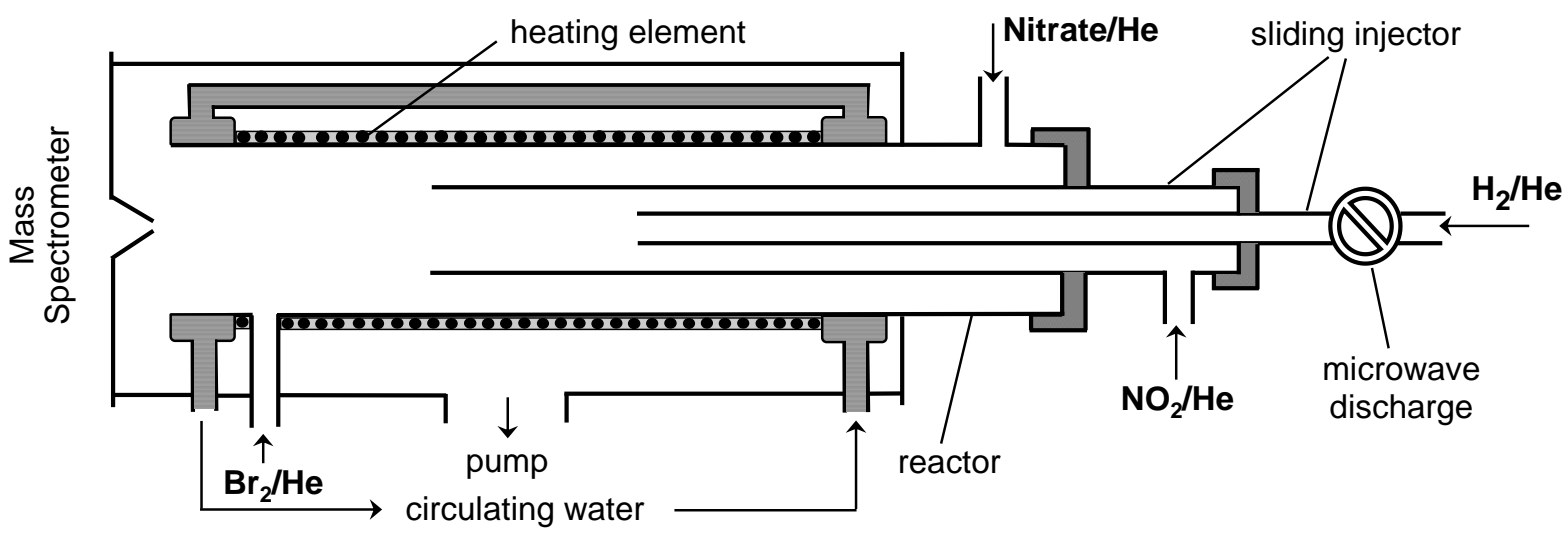

Fig. S1. Diagram of the flow reactor

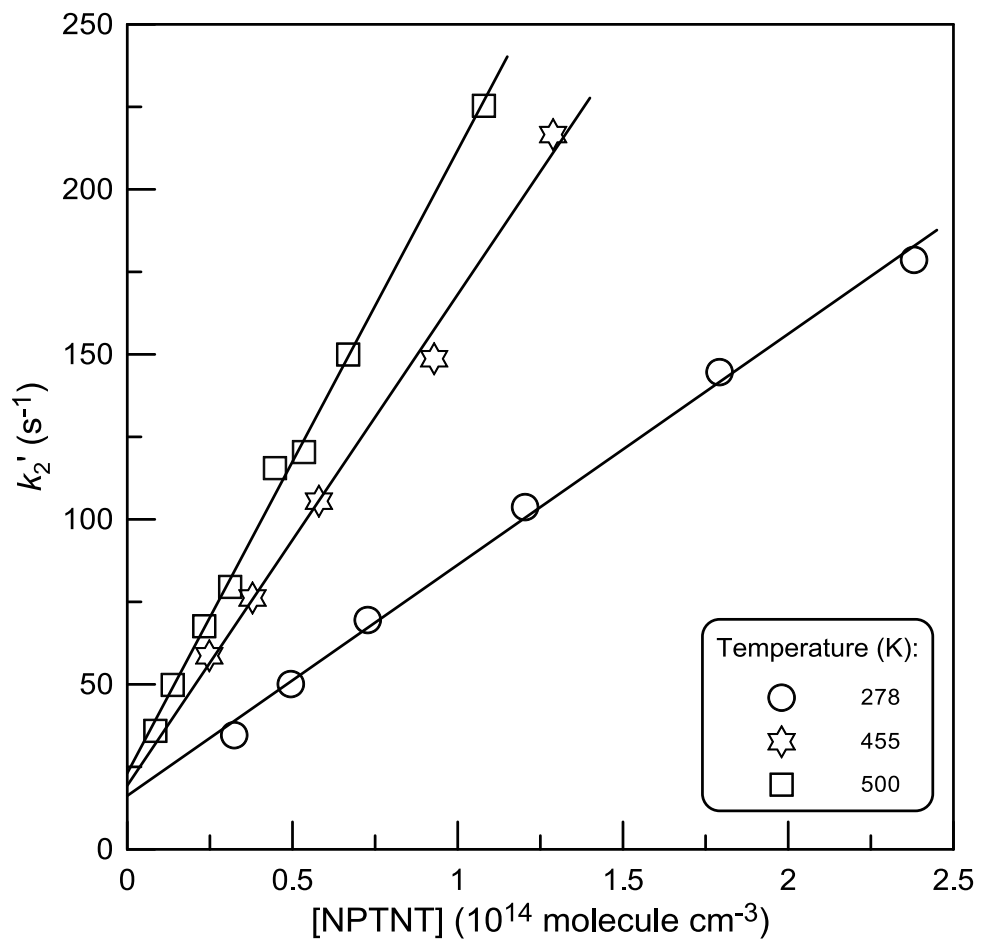

Fig. S2. Pseudo-first-order rate constant $\left(k_{2}{ }^{\prime}\right)$ as a function of the concentration of neopentyl nitrate at $\mathrm{T}=$ 278,455 and $500 \mathrm{~K}$. 


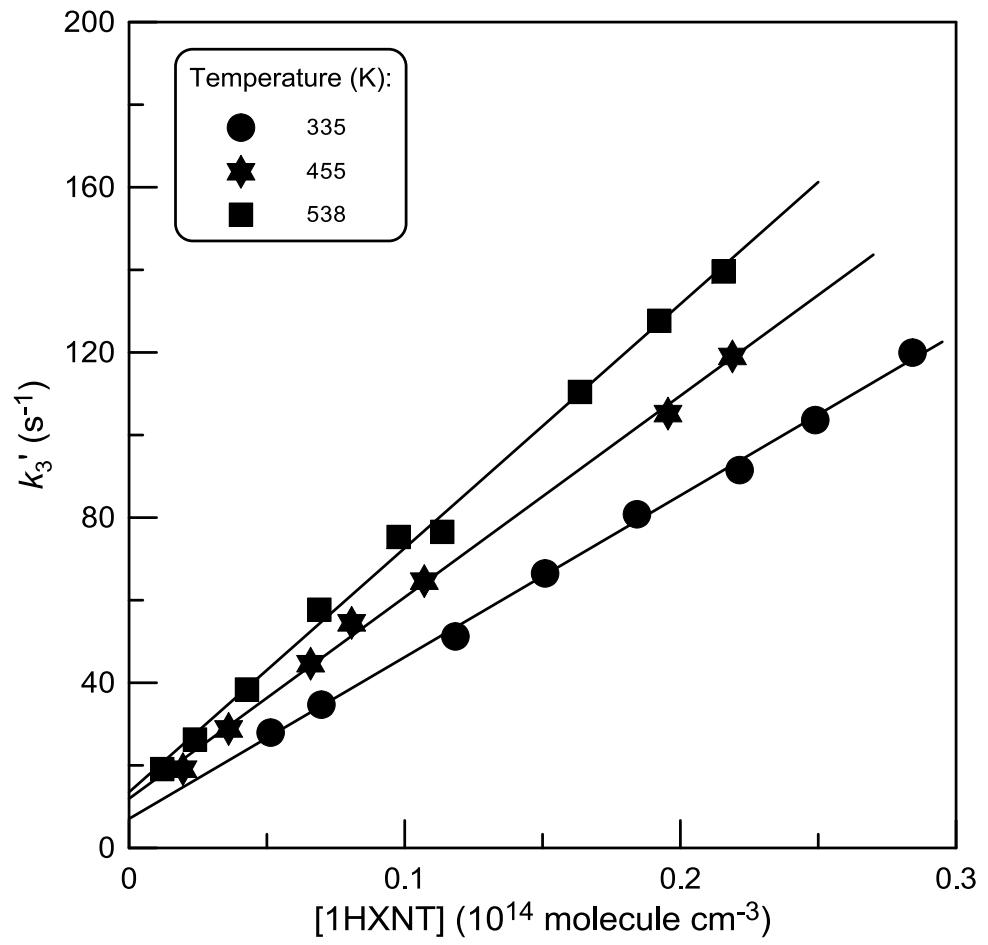

Fig. S3. Pseudo-first-order rate constant $\left(k_{3}{ }^{\prime}\right)$ as a function of the concentration of 1-hexyl nitrate at $\mathrm{T}=$ 335,455 and $538 \mathrm{~K}$.

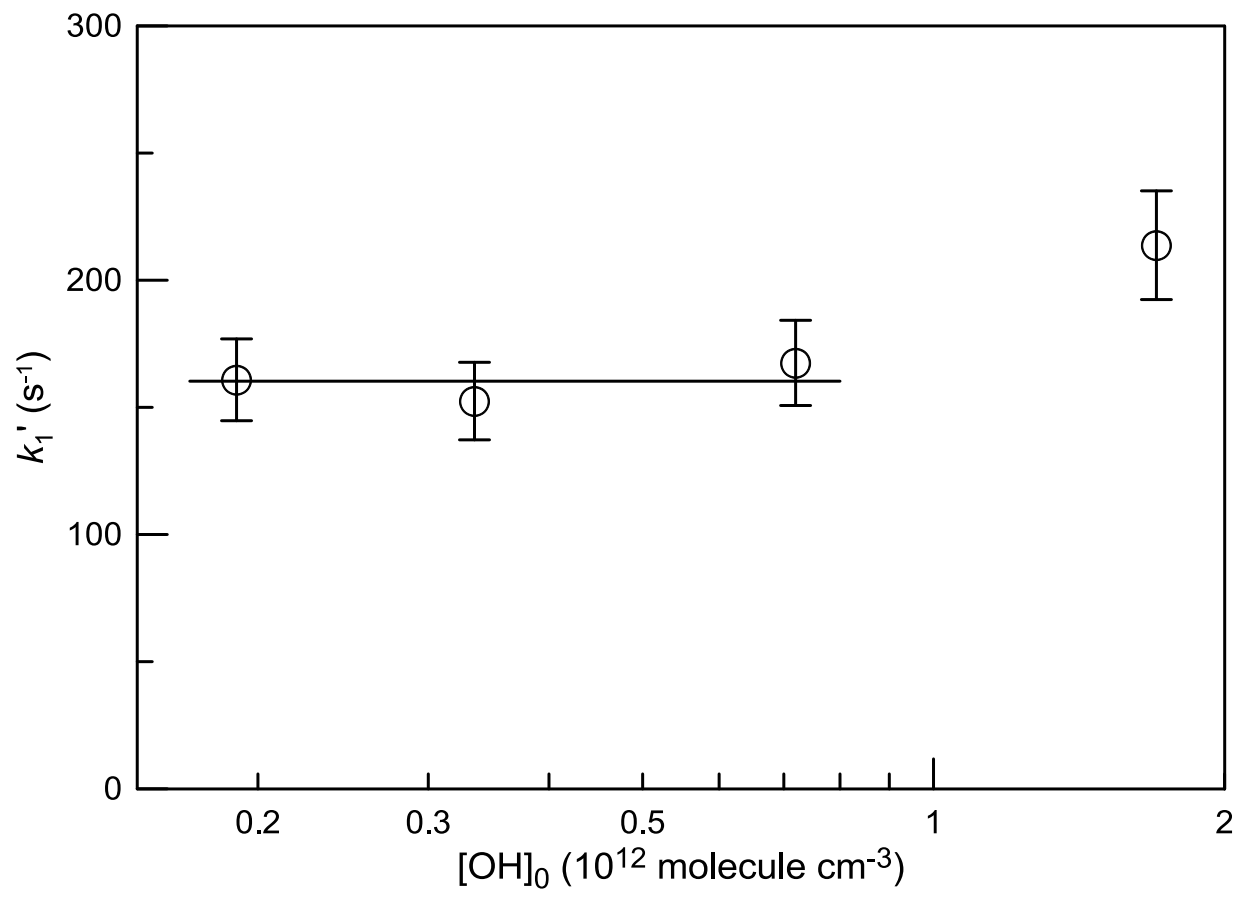

Fig. S4. Reaction $\mathrm{OH}+2$-methyl-1-butyl nitrate, $\mathrm{T}=298 \mathrm{~K},[2 \mathrm{M} 1 \mathrm{BNT}]=6.5 \times 10^{13}$ molecule $\mathrm{cm}^{-3}$ : dependence of $k_{1}{ }^{\prime}$ on initial concentration of $\mathrm{OH}$ radicals. 
Table S1.

Abbreviations for the Alkyl Nitrates Used in This Work.

\begin{tabular}{|c|c|c|}
\hline Chemical name & Chemical formula & Abbreviation \\
\hline methyl nitrate & $\mathrm{CH}_{3} \mathrm{ONO}_{2}$ & MNT \\
\hline ethyl nitrate & $\mathrm{CH}_{3} \mathrm{CH}_{2} \mathrm{ONO}_{2}$ & ENT \\
\hline 1-propyl nitrate & $\mathrm{CH}_{3}\left(\mathrm{CH}_{2}\right)_{2} \mathrm{ONO}_{2}$ & PNT \\
\hline isopropyl nitrate & $\left(\mathrm{CH}_{3}\right)_{2} \mathrm{CHONO}_{2}$ & IPNT \\
\hline 1-butyl nitrate & $\mathrm{CH}_{3}\left(\mathrm{CH}_{2}\right)_{3} \mathrm{ONO}_{2}$ & 1BNT \\
\hline isobutyl nitrate & $\left(\mathrm{CH}_{3}\right)_{2} \mathrm{CHCH}_{2} \mathrm{ONO}_{2}$ & IBNT \\
\hline 1-pentyl nitrate & $\mathrm{CH}_{3}\left(\mathrm{CH}_{2}\right)_{4} \mathrm{ONO}_{2}$ & 1PNNT \\
\hline isopentyl nitrate & $\left(\mathrm{CH}_{3}\right)_{2} \mathrm{CHCH}_{2} \mathrm{CH}_{2} \mathrm{ONO}_{2}$ & IPNNT \\
\hline neopentyl nitrate & $\left(\mathrm{CH}_{3}\right)_{3} \mathrm{CCH}_{2} \mathrm{ONO}_{2}$ & NPNNT \\
\hline 2-methyl-1-butyl nitrate & $\mathrm{CH}_{3} \mathrm{CH}_{2} \mathrm{CH}\left(\mathrm{CH}_{3}\right) \mathrm{CH}_{2} \mathrm{ONO}_{2}$ & 2MBNT \\
\hline 1-hexyl nitrate & $\mathrm{CH}_{3}\left(\mathrm{CH}_{2}\right)_{5} \mathrm{ONO}_{2}$ & HXNT \\
\hline 2-butyl nitrate & $\mathrm{CH}_{3} \mathrm{CH}_{2} \mathrm{CH}\left(\mathrm{CH}_{3}\right) \mathrm{ONO}_{2}$ & 2BNT \\
\hline 2-pentyl nitrate & $\mathrm{CH}_{3} \mathrm{CH}_{2} \mathrm{CH}_{2} \mathrm{CH}\left(\mathrm{CH}_{3}\right) \mathrm{ONO}_{2}$ & 2PNNT \\
\hline 3-pentyl nitrate & $\mathrm{CH}_{3} \mathrm{CH}_{2} \mathrm{CH}\left(\mathrm{ONO}_{2}\right) \mathrm{CH}_{2} \mathrm{CH}_{3}$ & 3PNNT \\
\hline 3-methyl-2-butyl nitrate & $\left(\mathrm{CH}_{3}\right)_{2} \mathrm{CHCH}\left(\mathrm{ONO}_{2}\right) \mathrm{CH}_{3}$ & $3 \mathrm{M} 2 \mathrm{BNT}$ \\
\hline 2-hexyl nitrate & $\mathrm{CH}_{3}\left(\mathrm{CH}_{2}\right)_{3} \mathrm{CH}\left(\mathrm{CH}_{3}\right) \mathrm{ONO}_{2}$ & $2 \mathrm{HXNT}$ \\
\hline 3-hexyl nitrate & $\mathrm{CH}_{3} \mathrm{CH}_{2} \mathrm{CH}_{2} \mathrm{CH}\left(\mathrm{ONO}_{2}\right) \mathrm{CH}_{2} \mathrm{CH}_{3}$ & 3HXNT \\
\hline 2-methyl-2-pentyl nitrate & $\mathrm{CH}_{2} \mathrm{CH}_{2} \mathrm{CH}_{2} \mathrm{C}\left(\mathrm{CH}_{3}\right)_{2} \mathrm{ONO}_{2}$ & 2M2PNNT \\
\hline 3-methyl-2-pentyl nitrate & $\mathrm{CH}_{3} \mathrm{CH}\left(\mathrm{ONO}_{2}\right) \mathrm{CH}\left(\mathrm{CH}_{3}\right) \mathrm{CH}_{2} \mathrm{CH}_{3}$ & 3M2PNNT \\
\hline 3-heptyl nitrate & $\mathrm{CH}_{3}\left(\mathrm{CH}_{2}\right)_{3} \mathrm{CH}\left(\mathrm{ONO}_{2}\right) \mathrm{CH}_{2} \mathrm{CH}_{3}$ & 3HPTNT \\
\hline 3-octyl nitrate & $\mathrm{CH}_{3}\left(\mathrm{CH}_{2}\right)_{4} \mathrm{CH}\left(\mathrm{ONO}_{2}\right) \mathrm{CH}_{2} \mathrm{CH}_{3}$ & 3OCTNT \\
\hline
\end{tabular}

